\title{
The Children Playing Activities of Suku Anak Dalam at Madobag Village Mentawai Regency
}

\author{
Gusril ${ }^{1 *}$, Tjung Hauw $\operatorname{Sin}^{2}$
}

\author{
Faculty of Sport Science, Universitas Negeri Padang, Indonesia \\ *Corresponding author. Email: nasir_gusril@yahoo.co.id
}

\begin{abstract}
The purpose of this research is to determine the playing activities of the children of Suku Anak Dalam at Madobag Village Mentawai Regency. This is a quantitative research. The population of this research consists of 93 students of public elementary school located at Madobag Village Mentawai Regency. Purposive sampling technique was used to select the sample and 42 students were selected. The instrument used was the questionnaire of Likert Scale. The techniques of data analysis used were inferensial. The data analysis of the research can be described as follow: male playing activities consist of: high score was 113, low score was 78, Mean was 98,82, Deviation Standard was 9,34, Median was 99, and Mode was 96. Female playing activities consist of: high score was 113, low score was 87, Mean was 100.57, Deviation Standard was 6.70, Median was 102, and Mode was 97. By using t formula, it was then found: $t$ obtained 0,811 > t table 1,62. It can be concluded that the children playing activities of Suku Anak Dalam at Madobag Village Mentawai Regency are not different between male and female. It can be concluded that the children playing activities of Suku Anak Dalam at Madobag Village Mentawai Regency are not genderly different.
\end{abstract}

\section{Keywords: Children Playing Activities, Suku Anak Dalam, Gender}

\section{INTRODUCTION}

Mentawai is one of the regencies classified as a regency which is far left behind in West Sumatra. Mentawai Regency consists of Siberut island, Sipora island, North and South Pagai island which is surrounded by oceans[1]. In order to develop the human resources, the government of Mentawai established primary schools, junior high schools and high schools [2]. Madobag Elementary School (SD) is one of the schools located on the island of Siberut that provides supplies to students to continue their education to the higher level through the subjects. One of the subjects in the general education program is Physical Education (Penjas). Penjas is an "educational process that utilizes bodily activities planned systematically aimed at increasing individuals organically, neuromuscularly, perceptively, cognitively, socially and emotionally" [3]. Penjas should be oriented to the process of achieving success in the development of the child as a whole into a complete human being. In this case, the learning process is oriented to high learning activities and pleasure.

When the learning activities are high and there is a sense of fun doing Penjas, the elementary school students will surely take advantages of their study time with the activities of motion and joy. The advantage of doing it is that students have knowledge of various movements and motivation to do the activities. Children playing activities are influenced by the interests and opportunities. If the children were given the opportunity to play the game since their childhood, they will be surely able to play the game well. Conversely, if they are not given the opportunity to play the game, their motivation decreases to do the activities.

State that playing is how children express their thoughts, feelings, and explore the world of their environment including helping children in social relationships among children[4]. Children's participation encourages them in planning, evaluating activities and choosing what they can do or play. Playing for children is a central theme that must be done every day of their life. It gives plenty of time to do something with imagination and the environment appropriately.

Playing activity is an activity that gives freshness to physical and psychic pleasure through physical activity. Pleasure arises when people play it well. If they do not do it seriously, it means that they are unhappy to play or feel unwell. Playing activity has become a reality and is widespread in society such as: children, youth, adults (male or female) both rich and poor get involved in the game. Pleasure arises and is fulfilled in playing activities when they play seriously. Problem arising in the activities is that there is no model of activities for elementary school students of Madobag Village Mentawai Regency.

One of relevant studies on children's playing activities and how to play is a mechanism for the socialization of childhood. Although this research has not been applied to 
sports socialization, it has an impact on the socialization of gender roles (ie, stereotypical learning of the gender roles of the community), which affects future girls' participation in sports. In general, this study shows that boys 'and girls' playing activities contribute to the development of different skills, preferences, and abilities, which can affect expectations, outcomes, and even future expectations.

A number of factors are known to have an impact on playing activities in children. Studies consistently find boys are more active than girls. The number of playrooms may also be important, at least in young children. McGrew finds that there is little movement in high density conditions in children aged 3-4 years[5]. Loo finds that group play declined and solitary games increased in kindergarten children under the cramped conditions, and caused gross motor activity difficult. Motor skills have also been shown to affect children's playing activities. However, this relationship has never been tested in older children who usually have much larger outdoor playing areas available in schools, and who may have the flexibility to adjust to limited space.

The interaction of girls, especially during informal playing activities, is less enthusiastic, and more cooperative, compared to boys. Based on the existing phenomenon, it is necessary to do the research on the exploration of tribal children's playing activities (Madobag Mentawai primary school students). By conducting this research, it is expected that Penjas teachers can find out how far the activity of child play which is the impact of learning Penjas given and documentation of activity of child tribe in Madobag Mentawai. On the other hand, Helms and Turner say that playing is a way for children to express their thoughts, feelings, and ways of exploring the world of the environment including helping children in social relationships among children. Children's participation encourages them in planning, evaluating activities and choosing what they can play. Playing for children is a central theme that must be done every day of their life. This activity gives plenty of time to do something with imagination and the environment reasonably.

Playing activity is an activity that gives freshness to physical and psychic pleasure through physical activities. Pleasure arises when they play well. When they do not do it seriously, it means they are unhappy to play or feel unwell. Playing activity has become a reality and is widespread in society such as: children, youth, adults (male or female) both rich and poor get involved in the game. Pleasure arises and is fulfilled in playing activities when they play seriously.

It can be said that the activity of play is a spontaneous activity performed by the children in their environment by involving imagination, appearance, whole feeling, hands or whole body through physical activities. Racick states that early childhood of schooling wants four or five hours of minimum each day activities of physical activity, while teenagers want half to two hours. On the other hand, the Offord study results concluded that boys and girls aged 5 to 12 in Canada spend about 14 hours a week in physical activity. It is added only a third of children who do activities that release enough energy for health that is useful for growth.

The type of play can be grouped into three parts consisting of: (a) active play; (b) passive play; (c) intellectual play. Active type of play is characterized by following various games and followed by physical movement, among others: gymnastics, swimming and chasing. In this active play, the children will benefit in terms of physical, mental, social, and emotional.

Passive playing type of children has more activities on enjoying (watching) game. Pleasure is earned only by seeing his friend doing the activity of playing. But in terms of physical, this type of passive play is clearly not profitable. This type of intellectual play is a form of game that requires deep thinking with concentrated concentration such as: chess, bridge.

States the values contained in playing activities are: (a) mental values consisting of: the child's need for new experiences, sense of security, self-acknowledgment, participation, pleasure; (b) physical values; (c) social value. The mental values contained in playing activities are as follows: (a) the child becomes aware of his rights and learns to respect others; (b) trusting each other among playmates; (c) knowing deficiencies, when compared to others. Moreover, children also admitted honestly the advantages of people and control the emotions of excessive motion. In addition, the children in the playing activity will also know their own dexterity, intelligence, responsibility, courtesy. It will increase the confidence of children in the face of every playing activity.

The physical values contained in playing activities are useful for the growth and development of children in terms of physical, mental and emotional social function. Playing activities require active gestures and are performed with great excitement. Exciting playing activities will affect hormones and stimulate growth. In addition, outdoor playing activities are good for breathing because the air is pollution-free. Children in playing activities can run, jump, crawl, push, and lift.

The movements involved affect the circulation of blood and breathing. The blood circulation works harder to pump blood throughout the body. Consequently, the work of the heart becomes stronger and its frequency is accelerating. Breathing will become deeper and faster. The deep and rapid respiratory effects result in the air-related lung surface becoming more widespread and allowing more oxygen uptake.

Thus, it can be concluded that playing activity is beneficial for heart and respiratory muscles and improve the reality of organs associated with breathing. It is said that playing activity can improve the work of blood circulation, the heart is more trained and can pump blood throughout the body. The lungs are trained to take as much oxygen as possible.

The social values contained in the playing activity consist of learning to give and accept the opponent to play, measuring strength, ability, intelligence, self-endurance with strength, ability, intelligence and tenacity of others. Children learn to recognize opponent's superiority, realize self-deficiency, recognize opponents playing as playmates. 
If it is a child againts a group, children surely have the opportunity to learn to deal with the crowd. Therefore, the child has an assessment that the group also has advantages and disadvantages.

Finally, the child has tactics and strategies to deal with the group. Other examples of group situations versus clusters contained in them social values such as: a sense of unity, togetherness, responsibility, cooperation, feeling or attitude prioritizing group interests rather than personal interests. In addition, it also fosters the attitude of sportsmanship, among others, by showing the attitude of obeying all the rules, distancing hate and resentment feelings.

The main task of the game is not victory but it is brotherhood. Thus, a game that has good quality in terms of techniques and tactics was displayed. When the game has been carried out with a high sportsmanship, there will certainly arise satisfaction for those who do it.

The functions of play in education field are as follows: (a) one of the ways to bring children to live together or community; (b) the child knows his or her strength, playground and nature; (c) revealing fantasy, all its original attributes which are performed in a compliant and courteous manner; (d) expressing all kinds of emotions; (e) for fun, joy, and happiness; (f) fostering cooperation, obedience to the rules, honest and all will shape the nature of fair play.

There are several benefits gained from playing activities that include physical activity for children as follows: (a) wasting extra energy; (b) optimizing the growth of all parts of the body such as bones, muscles, and organs; (c) increasing the child's appetite; (d) the child learns to control himself; (e) the development of skills that will be useful throughout his life; (f) enhancing creativity; (g) getting a chance to discover the meaning of the objects around him; (h) a way of overcoming anger, anxiety, envy and position; (i) the opportunity to learn to get along with other children; (j) the chance to be the loser or win in the play; (k) the opportunity to learn to follow the rules; (l) developing his intellectual ability.

Playing activities in sports, meant for locomotor movement in the context of the game. As in childhood, most studies of peer-to-peer activity focus only on pretending games, not physical activity in play. Exercise seems to increase from toddlers to pre-school years and then decreases in elementary school years, with peaks likely around 4 to 5 years (Eaton \& Yu, 1989; Routh, Schroeder, \& O'Tuama, 1974). 2 years of age, Rosenthal (1994) reported that about $7 \%$ of the behaviors observed in daycares. For children aged 2 to 4, Field (1994) "declared physical activity in play for $10 \%$ of all childcare behaviors"[5]. In Senegal found that gross motor activity is about $11 \%$ and $13 \%$ of children play at home at ages 2 to 4 and 5 to 6 years[6]. Describes the general level of playing activities of British elementary school children in school parks and found that most (60\% of children) were involved in some form of physically active game or play during rest periods, lasting between 65 and 75 minute[6].

\section{METHOD}

The design of this research was a quantitative research with comparison formula. The population of this research consists of 93 students of the public elementary school at Madobag Village Mentawai Regency. The sample was taken based on the Purposive sampling technique and found 42 students as the samples. The instruments used in this research were the questionnaire of Likert Scale in which the validity was 0,74 and reliability was 0,90 and observation form. The techniques of data analysis used were descriptive and inferential.

\section{RESULT}

Data Description

The Activity Data of Male Students Play

Based on the data of playing activities of male students, it was obtained the highest score with a score of 113 and the lowest score 78. Average Score of 98.82, Deviation Standard of 9.34, Median of 99 and Modus of 96. The frequency distribution of male students' playing activity score can be seen in the table 1 .

Table 1. Frequency Distribution of Male Student Playing Activities

\begin{tabular}{|c|l|l|l|}
\hline No & Interval & Fa & Fr (\%) \\
\hline 1 & $78-84$ & 2 & 8,70 \\
\hline 2 & $85-91$ & 3 & 13,04 \\
\hline 3 & $92-98$ & 6 & 26,09 \\
\hline 4 & $99-105$ & 5 & 21,74 \\
\hline 5 & $106-112$ & 6 & 26,09 \\
\hline 6 & $113-119$ & 1 & 4,35 \\
\hline \multicolumn{2}{|r|}{} & 23 & 100,00 \\
\hline
\end{tabular}

The table 1 shows that out of 23 students in grades 78 84 ( 2 persons $8.70 \%$ ), grades 85 - 91 (3 persons $13.04 \%$ ), grades $92-98$ (6 persons $26.09 \%)$, value $99-105(5$ people $21,74 \%$ ), value $106-112$ (6 person $26,09 \%$ ), value 113 - 119 (1 person 4,35\%). For more details variable of Male Student Playing Activity can be seen in the following histogram:

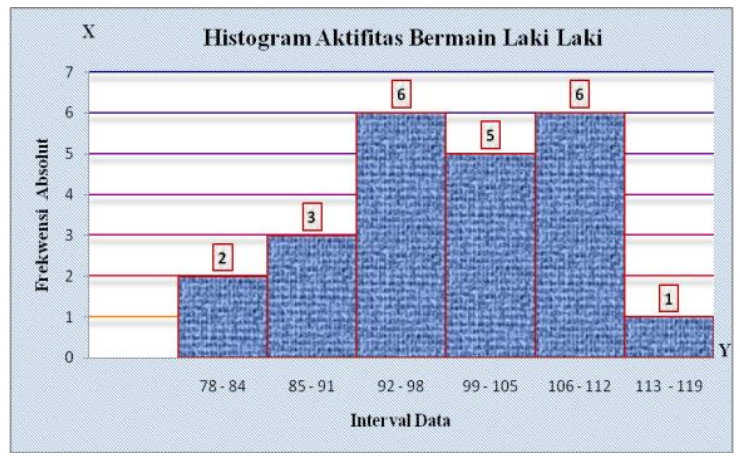

Data of Female Student Activity.

Based on the data play activities obtained the highest score with a value of 113 and the lowest score 87. From the data analysis known Average score of 100.57, Standard deviation of 6.70, Median of 102 and Mode of 
97. The frequency distribution score of female students play activity seen in the following table 2 .

Table 2. Frequency Distribution of Female Student Play Activity.

\begin{tabular}{|l|l|l|l|}
\hline No & Interval & Fa & Fr (\%) \\
\hline 1 & $87-91$ & 2 & 10,53 \\
\hline 2 & $92-96$ & 2 & 10,53 \\
\hline 3 & $97-101$ & 5 & 26,32 \\
\hline 4 & $102-106$ & 7 & 36,84 \\
\hline 5 & $107-111$ & 2 & 10,53 \\
\hline 6 & $112-115$ & 1 & 5,26 \\
\hline & & $\mathbf{1 9}$ & $\mathbf{1 0 0 , 0 0}$ \\
\hline
\end{tabular}

The table 2 shows that of 19 students in grades $87-91$ ( 2 persons $10.53 \%$ ), grades 92 - 96 (2 persons $10.53 \%), 97$ - 101 ( 5 people $26.32 \%$ ), values of 102 to 106 ( 7 persons $36.84 \%$ ), grades $107-111$ ( 2 persons $10.53 \%$ ), grades 112 - 115 (1 person 5.26\%). For more details variable activity of playing female students can be seen the following histogram.

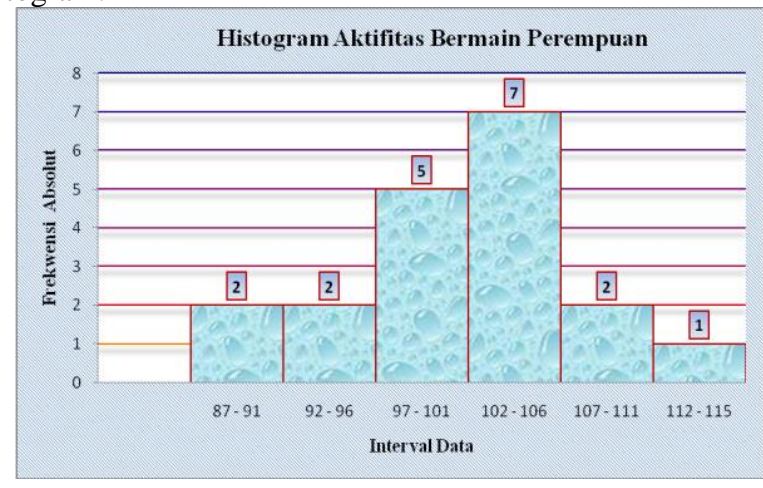

Based on the data analysis of the research described as follow: male playing activities consist of: high score was 113, low score was 78, Mean was 98,82, Deviation Standard was 9,34, Median was 99, and Mode was 96. Female playing activities consist of: high score was 113, low score was 87 , Mean was 100.57, Deviation Standard was 6.70, Median was102, and Mode was 97. By using $t$ formula, it is then found: $t$ obtained $0,811>t$ table 1,62 . It can be concluded that the children playing activities of Suku Anak Dalam at Madobag Village Mentawai Regency has no significant difference between male and female.

\section{CONCLUSION}

Based on the data analysis, it can be concluded that the children playing activities of Suku Anak Dalam at Madobag Village Mentawai Regency, are not genderly different. The finding of the research implies the construction of playing activities model relevant with $S u k u$ Anak Dalam Madobag Village Mentawai Regency.

\section{REFERENCES}

[1] Darmanto \& Setyowati, Abidah B, "Berebut Hutan Siberut, orang Mentawai Kekuasaan, dan Politik Ekologi," Jakarta; Gramedia bekerjasama dengan UNESCO. 2012

[2] Rudito, Bambang, "Bebeitei Uma: Jati Diri Orang Mentawai," Jakarta; Indonesia Center Sustainable Development. 2006

[3] Gusril, "Perkembangan Motorik Pada AnakAnak," Padang; UNP Press, pp, 67-75. 2016.

[4] Helms, Donald B and Jeffrey S. Turner, "Child Behavior," New York; Holt, Rinehart and Winston. 1981

[5] Field, T. M, "Infant day care facilitates later social behavior and school performance," In E. V. Jacobs \& H. Goelman (Eds.), "Children's play in child care settings," Albany; State University of New York Press, pp, 69-84. 1994.

[6] Bloch, M. N, "Young boys' and girls' play in the home and in the community: A cultural ecological framework. In M. N. Bloch \& A. D. Pellegrini (Eds.), "The ecological context of children's play," Norwood NJ; Ablex, pp, 120-154. 1989. 